\title{
The Cytological Composition of the Foetal Endocrine Pancreas in Normal and Pathological Conditions
}

\author{
F.A. van Assche and W. GRPTS \\ Laboratory of Gynaecological Physiopathology, University of Leuven, Laboratory of Pathology, University of Brussels \\ Belgium
}

Received: May, 4, 1971, accepted: September 9, 1971

Summary. The islets of Langerhans of the neonatal pancreas are composed of $B$ cells and non- $B$ cells. The non-B cells are a heterogeneous group and the composition appears to vary according to the staining method used. Silver impregnation methods sometimes impregnate a small number of B cells. No complete identity exists between argyrophilic cells (Hellerström-Hellman modifications of the Davenport technique) and D cells. In babies from mothers with reduced carbohydrate tolerance the islets contain an increased proportion of $\mathrm{B}$ cells and $\mathrm{Ag}^{+}$ cells. Such an increase is not found in babies with erythroblastosis or alpha-thalassaemia. An active hypothalamo. hypophyseal system seems to be obligatory for complete maturation of the foetal islet tissue. In babies of diabetic mothers hyperplasia of the B cell appears only when a complete hypothalamo-hypophyseal system is present.

La composition cytologique du paneréas endocrine foetal dans les conditions normales et pathologiques

Résumé. Les îlots de Langerhans du pancréas néonatal sont composés de cellules $\mathbf{B}$ et de cellules non-B. Les cellules non-B forment un groupe hétérogène, dont la composition varie selon la technique de coloration. L'imprégnation argentique marque un petit nombre de cellules $B$. Il n'y a pas d'équivalence entre les cellules argyrophiles (modifications de Hellerström et Hellman de la technique de Davenport) et les cellules D. Il existe une augmentation du rapport cellules $B$ et cellules argentaffines dans les îlots de Langerhans d'enfants dont la mère présente un métabolisme glucidique perturbé. Ce phénomène n'a pas pu être mis en évidence chez les enfants présentant de l'éry. throblastose ou de l'alpha thalassémie. On peut admettre la nécessité d'un système hypothalamo-hypophysaire actif pour la maturation complète des îlots foétaux. On constate chez les enfants de mères diabétiques une hyperplasie des cellules B lorsqu'un système hypothalamo-hypophysaire complet est présent.

Die cytologische Zusammensetzung des foetalen endokrinen Pankreas unter normalen und pathologischen Bedingungen

Zusammenfassung. Die Langerhans'schen Inseln des neonatalen Pankreas bestehen aus $B$ Zellen und nicht-B Zellen. Die nicht-B Zellen bilden eine heterogene Gruppe, deren Zusammensetzung je nach der gebrauchten Färbungsmethode ändert. Silberimprägnierungsmethoden imprägnieren eine kleine ZahI B Zellen. Es besteht keine vollständige Identität zwischen argyrophilen (nach Davenport-Hellerström-Hellman) Zellen und D Zelle. Bei den Neugeborenen von Müttern mit reduzierter Kohlenhydrattoleranz enthalten die Inseln eine größere Proportion B Zellen und Ag + Zellen. Fine solche Zunahme fehlt bei Neugeborenen mit Erythroblastose oder Alpha Tha. lassämie. Ein aktives hypothalamo-hypophysäres System ist notwendig um eine vollständige Reifung des foetam len-Insel-Gewebes zu erreichen. Bei Neugeborenen diabetischer Mütter kommt Hyperplasie der B Zellen nur dann vor, wenn ein vollständiges Hypothalamo-hypophysäres System anwesend ist.

Key words: Islet cells, B cells, argyrophilic cells, D cells, infants of diabetic mothers, anencephalics, anti-D. iso-immunization, pregnant diabetic, hypothalamo-hypophyseal system, perinatal mortality, diabetic screening.

\section{Introduction}

The cytological composition of the islets of Langer. hans in man is still uncertain. Besides A and B cells, other types of cells $\left(A^{1}, A^{2}, D\right.$ etc. $)$ have been described $[3,4,8,13,14,18,35,36]$. The identity of these unusual cell types and their functional significance has not been definitively settled. Evidence has been presented by the Swedish Sohool that $A^{2}$ cells secrete glucagon. The function of the $\mathrm{A}^{1}$ cells remains unknown. Some authors $[7,12,14]$ are of the opinion that these cells are identical to the $\mathrm{D}$ cells described by Bloom, but others $[3,19]$ are reluctant to admit this identity. Recent evidence suggests that the $\mathrm{A}^{1}$ cells secrete gastrin [29]. Furthermore, little work has been performed on the variation of the cytological composition of foetal islets in different pathological conditions.

Macropolynesia, due mainly to an increased number of $\mathrm{B}$ cells, is a classical feature of the pancreas in infants of diabetic mothers. Macropolynesia has also been found in babies affected by anti-D-erythroblastosis and by haemolysis due to alpha-thalassaemia $[6,9,11,25,30,31,34,37,38,39,41,42]$, but it has not been proven that in these latter conditions it is also due to an hyperplasia of the B cells $[2,5]$.

The purpose of this paper is to report our findings with different staining techniques on the cytological composition of the islets of the human newborns and its variations in different pathological conditions.

\section{Material and Methods}

The material for this study consists of the endocrine pancreases from 107 foetuses and newborn infants delivered after the 20 th week of gestation. 
The cases were classified according to the oral glucose tolerance test (G.T.T.) of the mother, and the condition of the offspring.

Group I: normal maternal G.T.T. during pregnancy or postpartum: 40 cases

Group II: slightly reduced carbohydrate tolerance: 9 cases

Group III: diabetes: 10 cases

Group IV: erythroblastosis (rhesus iso-immunization): 10 cases

Group V: hydrops foetalis due to alpha-thalassaemia: 5 cases

Group VI: anencephalics without functional hypothalamo-hypophyseal (H.H.) system

a) normal maternal G.T.T.: 9 cases

b) abnormal maternal G.T.T.: 8 cases

c) maternal G.T.T. not performed: 9 cases

Group VII: anencephalics with functional hypothalamo-hypophyseal (H.H.) system

a) normal maternal G.T.T.: 3 cases

b) abnormal maternal G.T.T.: 4 cases

Glucose tolerance tests were performed on the mother giving a standard load of $100 \mathrm{~g}$ glucose. Blood sugars were estimated on capillary blood before and $45,90,135$ and $180 \mathrm{~min}$ after the oral intake of $100 \mathrm{~g}$ glucose, by a method adapted from Nelson-Somogyi [32]. The glucose tolerance test was considered as normal if no more than one of the following values was exceeded:

1) fasting glucose level $100 \mathrm{mg} \%$;

2) at $45 \mathrm{~min}$

3) at $90 \mathrm{~min}$

4) at $135 \mathrm{~min}$

5) at $180 \mathrm{~min}$

$180 \mathrm{mg} \%$

$130 \mathrm{mg} \%$;

$120 \mathrm{mg} \%$;

$100 \mathrm{mg} \%$.

Slightly reduced carbohydrate tolerance was accepted if two or more values exceeded the above levels, and diabetes with two or more values exceeding the following levels:
1) fasting level
$120 \mathrm{mg} \%$;
2) at $45 \mathrm{~min}$
3) at $90 \mathrm{~min}$
4) at $135 \mathrm{~min}$
5) at $180 \mathrm{~min}$

$$
\begin{aligned}
& 210 \mathrm{mg} \% ; \\
& 170 \mathrm{mg} \% ; \\
& 150 \mathrm{mg} \% ; \\
& 135 \mathrm{mg} \% \text {. (Fig. 1) }
\end{aligned}
$$

All cases of erythroblastosis (anti-D iso-immunization) showed gross foeto-placental oedema. Except in one case the maternal oral glucose tolerance test was normal. In seven infants one or more intrauterine transfusions had been performed. Pancreatic tissue from infants with hydrops foetalis due to alpha thalassaemia was generously provided by Prof. L.E. Lie-Injo from Kuala Lumpur, Malaysia.

Anencephalics were classified in two groups, according to the absence (group VI) or presence (group VII) of a functional hypothalamo-hypophyseal (H.H.) system. Our criteria for the presence of a functional hypothalamo-hypophyseal system were:

1) macroscopical presence of a hypothalamo-hypophyseal structure;

2) demonstration of a foetal adrenal cortex by microscopical examination;

3) subnormal total oestrogen levels in maternal urine.

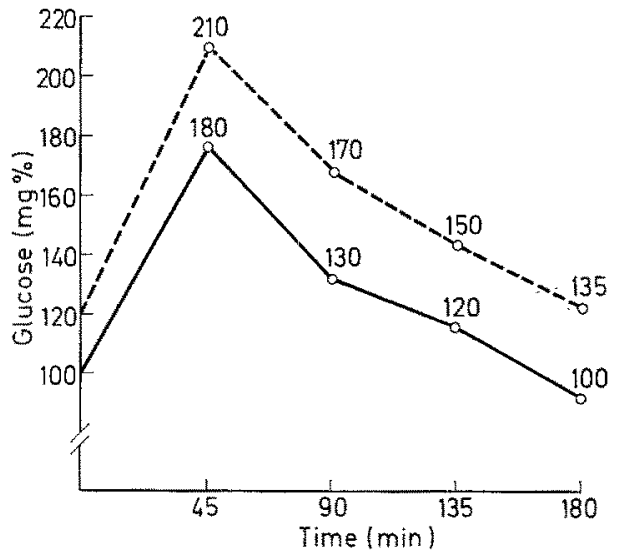

Fig. 1. Upper limits of normal glucose tolerance, and slightly reduced carbohydrate tolerance

In each of these groups, cases were subclassified according to the results of the oral glucose tolerance test (G.T.T.) in the mother. No distinction was made between slightly or frankly reduced carbohydrate tolerance.

The pancreas was removed within two hours of death and a piece of the tail was fixed in Bouin's solution for two days. Sections at 3 or $5 \mu$ were cut from paraffin-embedded tissue.

The following staining methods were used:

Gomori's chrome-alum haematoxylin-phloxine method [16];

Ivic's Victoria-blue acid-fuchsin method [24];

a modified aldehyde-thionin-trichrome method [33]; silver impregnation techniques

a) Hellerström-Hellman [18];

b) Holmes [22].

To evaluate the percentage of the different cell types 2000 cells were counted with the nucleus as counting base. All the cells of each islet were systematically counted.

For the comparison of the different cell types 3 methods were used:

In 10 cases alternate sections ( $3 \mu$ thickness) were prepared and coloured by the aldehyde-thionintrichrome method, by the silver impregnation technique (Hellerström-Hellman) and by Ivie's method.

In 10 cases slides were coloured by aldehyde-thionintrichrome or by Ivic's method after removal of silver by the oxidation process.

In 10 cases slides were counterstained by the aldehydethionin-trichrome method after silver impregnation (Holmes technique). 


\section{Results}

\section{The different cell types}

a) $B$ cells. As shown in Table 1, we did not find significant differences in the percentage of $\mathrm{B}$ cells among islet cells as demonstrated by three staining techniques (Gomori's chrome-alum phloxine method; Ivic's Victoria-blue acid-fuchsin; and aldehyde-thionin-trichrome).

Table 1. Percentage of $B$ cells with different staining techniques

\begin{tabular}{|c|c|c|c|}
\hline Number & $\begin{array}{l}\text { Gomori } \\
\text { ehrome } \\
\text { alum }\end{array}$ & Iric & $\begin{array}{l}\text { Aldehyde } \\
\text { thionin } \\
\text { trichrome }\end{array}$ \\
\hline 29 & 38 & 40 & 41 \\
\hline 37 & 31 & 28 & 30 \\
\hline 47 & 38 & 38 & 39 \\
\hline 50 & 35 & 34 & 37 \\
\hline 52 & 45 & 46 & 44 \\
\hline 53 & 36 & 37 & 37 \\
\hline 43 & 40 & 41 & 43 \\
\hline 118 & 62 & 63 & 65 \\
\hline 26 & 73 & 71 & 70 \\
\hline 32 & 49 & 50 & 48 \\
\hline 33 & 57 & 57 & 55 \\
\hline 56 & 63 & 66 & 65 \\
\hline 57 & 40 & 38 & 41 \\
\hline 84 & 58 & 59 & 56 \\
\hline 74 & 47 & 50 & 52 \\
\hline 42 & 40 & 43 & 45 \\
\hline 114 & 22 & 23 & 21 \\
\hline 121 & 39 & 40 & 41 \\
\hline 151 & 35 & 35 & 33 \\
\hline 119 & 58 & 56 & 55 \\
\hline Mean $t S$ & $45.3 \pm 12.7$ & $45.7 \pm 12.9$ & $45.9 \pm 12.4$ \\
\hline
\end{tabular}

The mean percentage of $B$ cells in the normal group is $40 \% \pm 7.5$ (M. \pm S.D.). B cell hyperplasia was defined as a percentage higher than $40 \%+15$ i.e. $55 \%$.

As shown in Table 2, we found hyperplasia of the $B$ cells in three groups (newborns from mothers with a slightly or frankly reduced carbohydrate tolerance, groups II and III; anencephalies from mothers with a reduced carbohydrate tolerance, provided that in these foetuses a functional hypothalamo-hypophyseal system was present, group VII b). The differences between these groups and the normal group are statistically significant $(p<0.001)$.

In the erythroblastotic group and in infants affected by alpha-thalassaemia we found a normal percentage of $\mathrm{B}$ cells.

b) Phloxine-positive cells. The B cells are situated in the centre of the foetal islets and are stained blue with Gomori's chrome-alum haematoxylin. With the same method all the other cells (non- B cells) are stained red (phloxine +) and are situated at the periphery ("mantle"). Therefore their proportion is complementary to that of the B cells (Fig. 2).

c) Acid-fuchsin-positive cells $(A F+)$ and acidfuchsin-negative cells $(A F-)$. In sections stained by
Iric's method we found two types of non-B cells in the mantle area: first, cells heavily stained with acid fuchsin $(\mathrm{AF}+-)$; and secondly, cells unstained or only slightly stained (AF -) (Fig. 3). The mean percentage of $\mathrm{AF}+$ and $\mathrm{AF}$ - cells is invariable in all groups studied. This is shown in Table 3.

Table 2. Percentage of $B$ cells in the different groups. Slides stained with Ivic's technigue

\begin{tabular}{|c|c|c|c|}
\hline \multicolumn{2}{|c|}{ Group } & \multirow{2}{*}{$\begin{array}{l}\text { Percentage of } \\
\text { B cells } \\
\text { M. } \pm \text { S.D. } \\
40 \pm 7.5\end{array}$} & \multirow{2}{*}{$\begin{array}{l}\text { B cell } \\
\text { hyper- } \\
\text { plasia } \\
\text { percent } \\
\text { of cases } \\
5\end{array}$} \\
\hline I & $\begin{array}{l}\text { Normal maternal G.T.T. } \\
n=40\end{array}$ & & \\
\hline III & $\begin{array}{l}\text { Slightly reduced carbohy- } \\
\text { drate tolerance } \\
n=9\end{array}$ & $54.8 \pm 12.3$ & 44 \\
\hline ITI & $\begin{array}{l}\text { Diabetes } \\
n=10\end{array}$ & $63.8 \pm 8.9$ & 90 \\
\hline $\mathrm{IV}$ & $\begin{array}{l}\text { Erythroblastosis } \\
\mathbf{n}=10\end{array}$ & $40 \pm 8$ & 10 \\
\hline $\mathrm{V}$ & $\begin{array}{l}\alpha \text {-Thalassamia } \\
n=5\end{array}$ & $39.8 \pm 3$ & 0 \\
\hline$\nabla I$ & $\begin{array}{l}\text { Anencephalics without } \\
\text { functional H.H. system } \\
\text { a) Normal G.T.T. } \\
n=9 \\
\text { b) Abnormal G.T.T. } \\
\text { n=8 } \\
\text { c) Without G.T.T. } \\
n=9\end{array}$ & $\begin{array}{l}40 \pm 6 \\
38 \pm 9.7 \\
37 \pm 9.8\end{array}$ & $\begin{array}{l}0 \\
0 \\
0\end{array}$ \\
\hline VII & $\begin{array}{l}\text { Anencephalics with func- } \\
\text { tional H.H. system } \\
\text { a) Normal G.T.T. } \\
\text { n=3 } \\
\text { b) Abnormal G.T.T. } \\
\text { n=4 }\end{array}$ & $\begin{array}{l}40,40,44 \\
54,70,59,56\end{array}$ & $\begin{array}{r}0 \\
75\end{array}$ \\
\hline
\end{tabular}

d) Green cells (D?) and red cells. In slides coloured with aldehyde-thionin-trichrome we found two types of cells in the mantle zone: green cells ( $D$ cells) and red cells (Fig. 4). As shown in Table 4, the percentage of $D$ cells was about the same in the different groups.

e) Silver-positive cells (argyrophilic cells). With the Hellerström and Hellman silver-impregnation technique, we found black-coloured cells $(\mathrm{Ag}+)$ and lightbrown coloured cells $(\mathrm{Ag}-)$ in the mantle area (Fig. 5).

In 12 babies of mothers with a normal glucose tolerance test a comparison was made between phloxine-positive cells (non-B cells) and $\mathrm{Ag}+$ cells. The mean value of phloxine-positive cells for these cases was $62 \%$ (Table 5). In silver-impregnated preparations only $40.5 \%$ of the islet cells were silver positive. This means that roughly only $65 \%$ of the phloxinepositive cells are argyrophilic. 


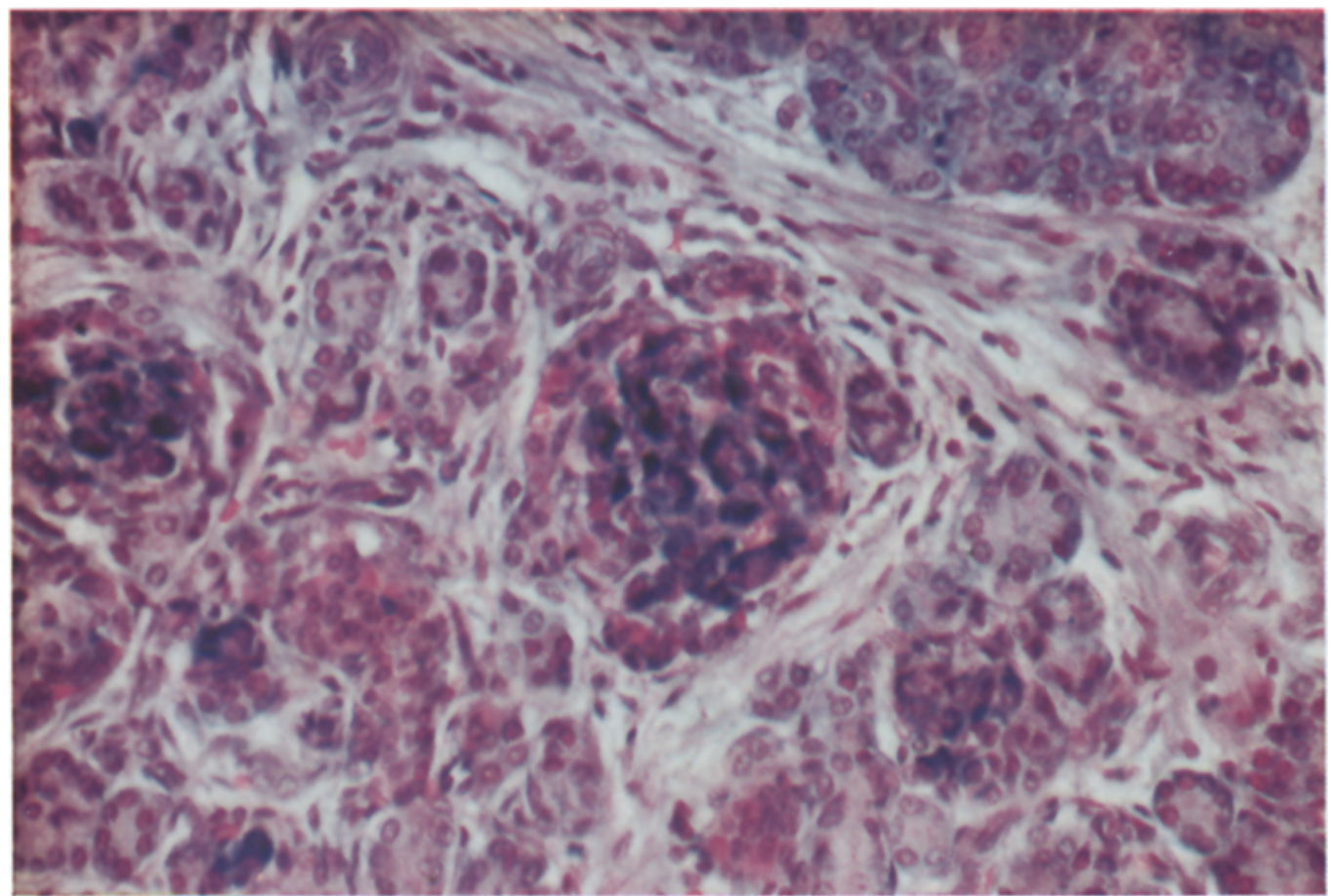

Fig. 2. The foetal islets are composed of a central core of $B$ cells (blue cells) and a peripheral area of non-B cells (red cells) Gomori-stained section

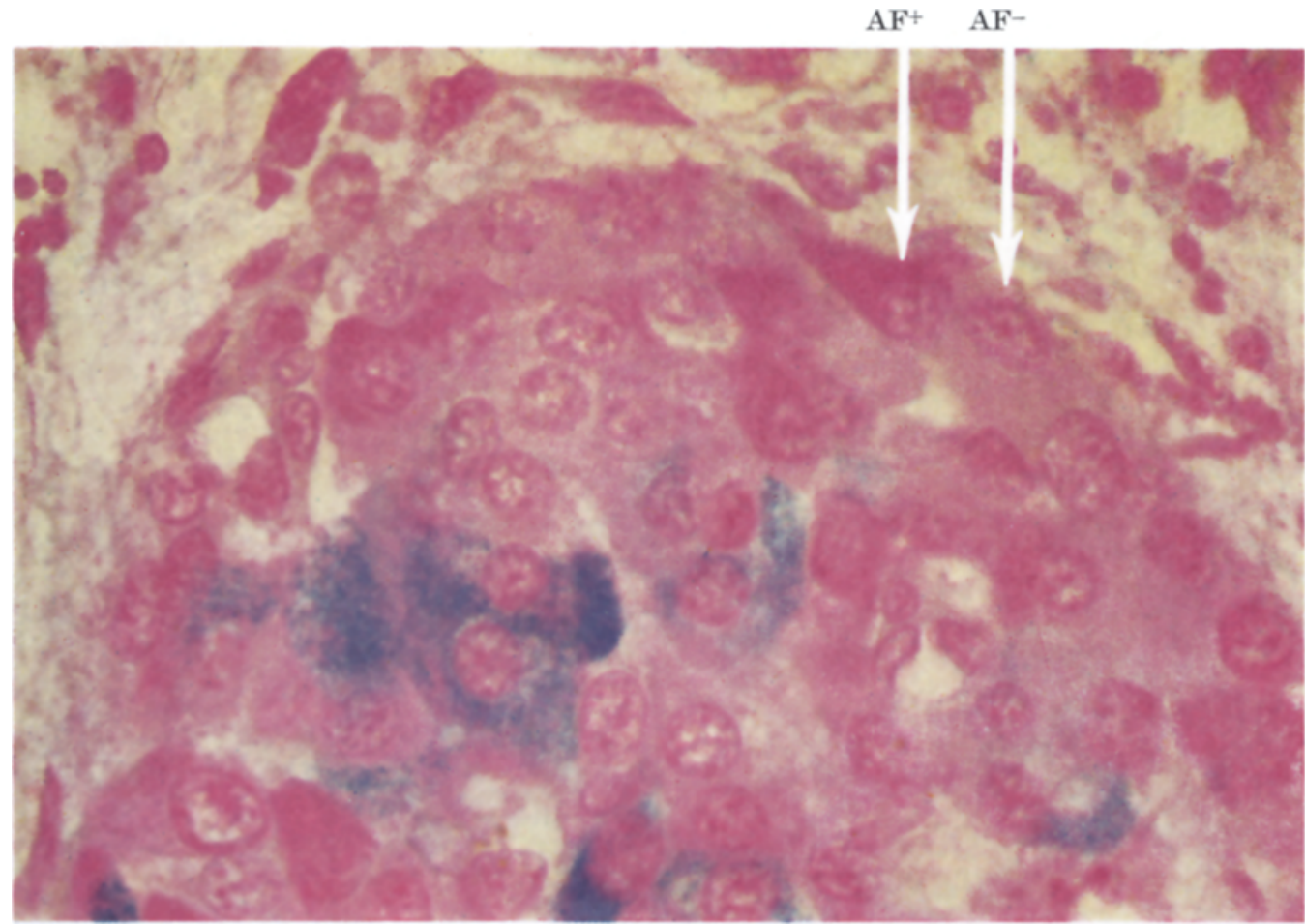

Fig. 3. Two types of non-B cells are present in the mantle area: first, cells very well coloured with acid fuchsin (AF + red); and secondly, cells slightly coloured or even not (AF-)

Section stained by Ivic's method. 


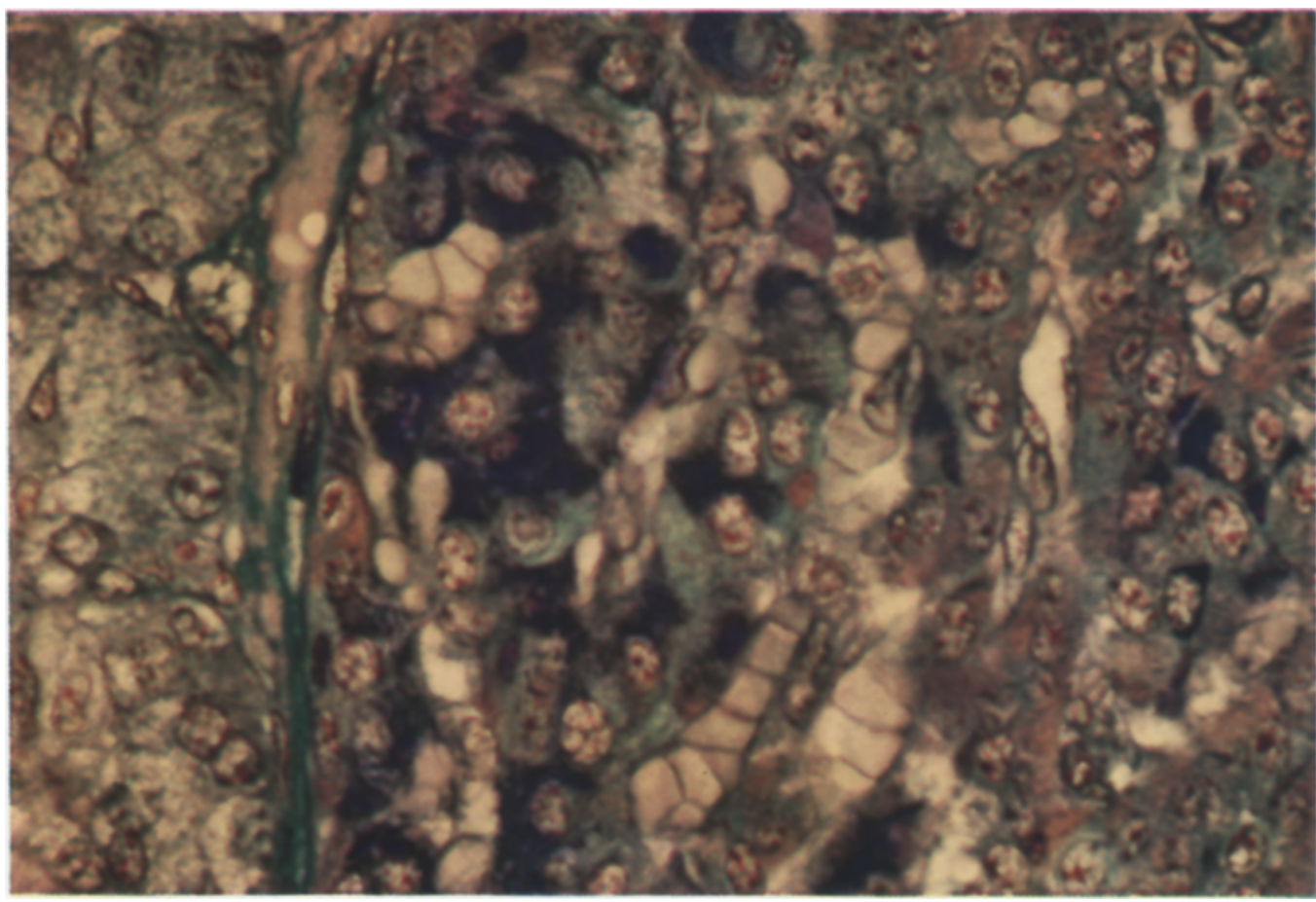

Fig. 4. Two types of non-B cells are seen in the mantle area: green cells (D cells ?) and red cells Aldehyde thionin trichrome stained section

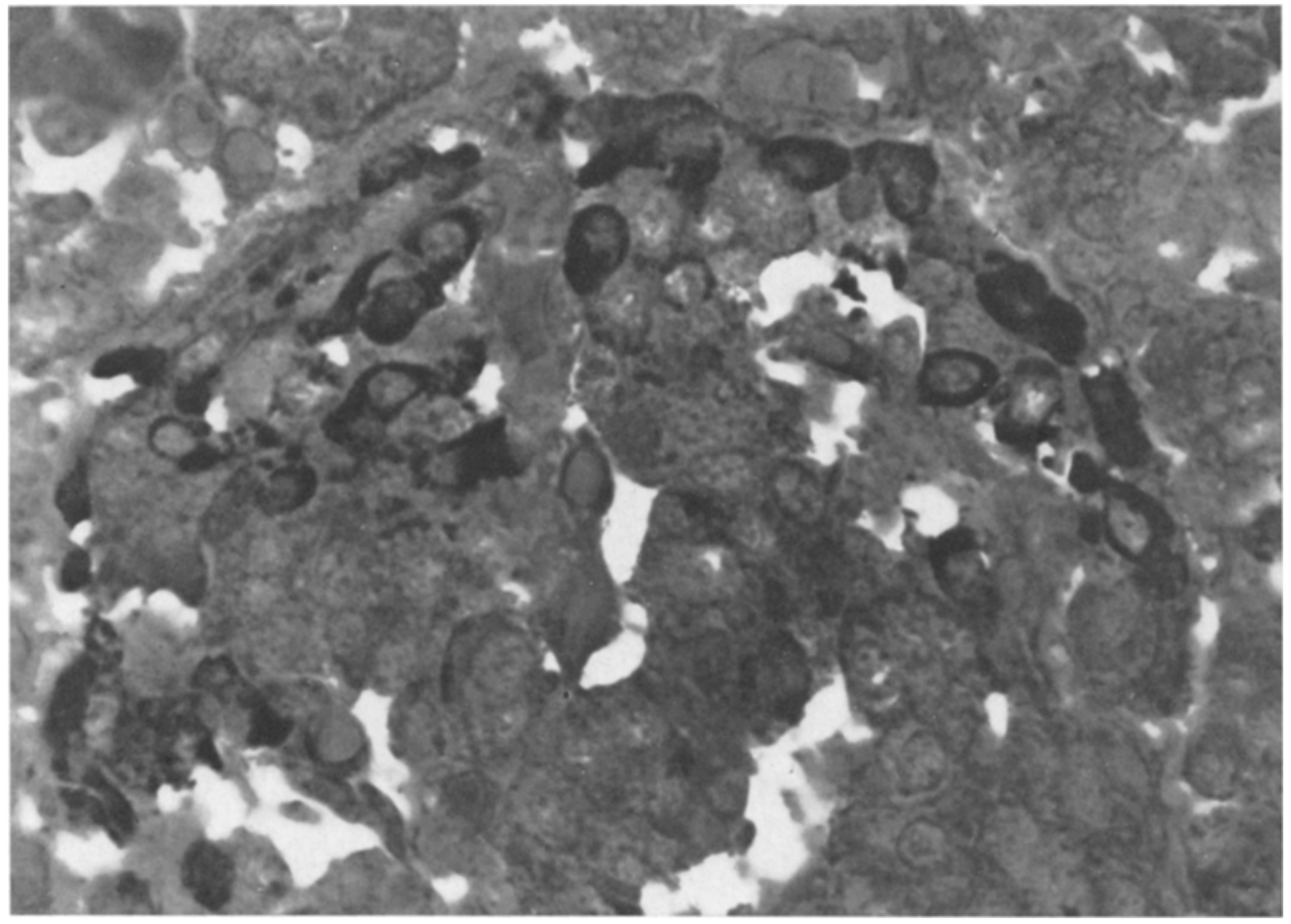

Fig. 5. Most of the black cells $(\mathrm{Ag}+)$ are situated in the peripheral area. In the central core most of the cells are brown $(\mathrm{Ag}-)$

Slide stained with Hellerström.Hellman silver impregnation technique 
Table 3. Percentage of $A F^{+}$and $A F^{-}$cells in the different groups

\begin{tabular}{|c|c|c|c|}
\hline \multicolumn{2}{|c|}{ Group } & $\begin{array}{l}\text { Percentage } \\
\mathrm{AF}+\text { cells } \\
\text { M. } \pm \text { S.D. }\end{array}$ & $\begin{array}{l}\text { Percentage } \\
\text { AF- cells } \\
\text { M. }+ \text { S.D. }\end{array}$ \\
\hline $\mathrm{I}$ & $\begin{array}{l}\text { Normal maternal } \\
\text { G.T.T. } \\
n=34\end{array}$ & $73.5 \pm 8.8$ & $26.5 \pm 8.8$ \\
\hline$\overline{\text { II }}$ & $\begin{array}{l}\text { Slightly reduced } \\
\text { carbohydrate toler- } \\
\text { ance } \\
n=7\end{array}$ & $73 \pm 6.6$ & $27 \pm 6.6$ \\
\hline$\overline{\text { III }}$ & $\begin{array}{l}\text { Diabetes } \\
n=9\end{array}$ & $83 \pm 3.2$ & $17 \pm 3.2$ \\
\hline$\overline{\mathrm{IV}}$ & $\begin{array}{l}\text { Erythroblastosis } \\
\mathrm{n}=6\end{array}$ & $76 \pm 7.9$ & $24 \pm 7.9$ \\
\hline $\mathrm{VI}$ & $\begin{array}{l}\text { Anencephalics with- } \\
\text { out functional H.H. } \\
\text { system } \\
\text { a) Normal G.T.T. } \\
\text { n=7 } \\
\text { b) Abnormal G.T.T. } \\
\text { n=5 } \\
\text { c) Without G.T.T. } \\
\text { n=5 }\end{array}$ & $\begin{array}{l} \\
\\
73 \pm 6.6 \\
77 \pm 5.8 \\
78 \pm 6.8\end{array}$ & $\begin{array}{l}27 \pm 6.6 \\
23 \pm 5.8 \\
22 \pm 6.8\end{array}$ \\
\hline$\overline{\text { VI] }}$ & $\begin{array}{l}\text { Anencephalics with } \\
\text { functional H.H. } \\
\text { system } \\
\text { a) Normal G.T.T. } \\
\mathrm{n}=2 \\
\text { b) Abnormal G.T.T. } \\
\mathrm{n}=3\end{array}$ & $\begin{array}{l}65,71 \\
76,64,78\end{array}$ & $\begin{array}{l}35,29 \\
24,36,22\end{array}$ \\
\hline
\end{tabular}

Table 4. Percentage of green (D?) cells and red cells in the different groups

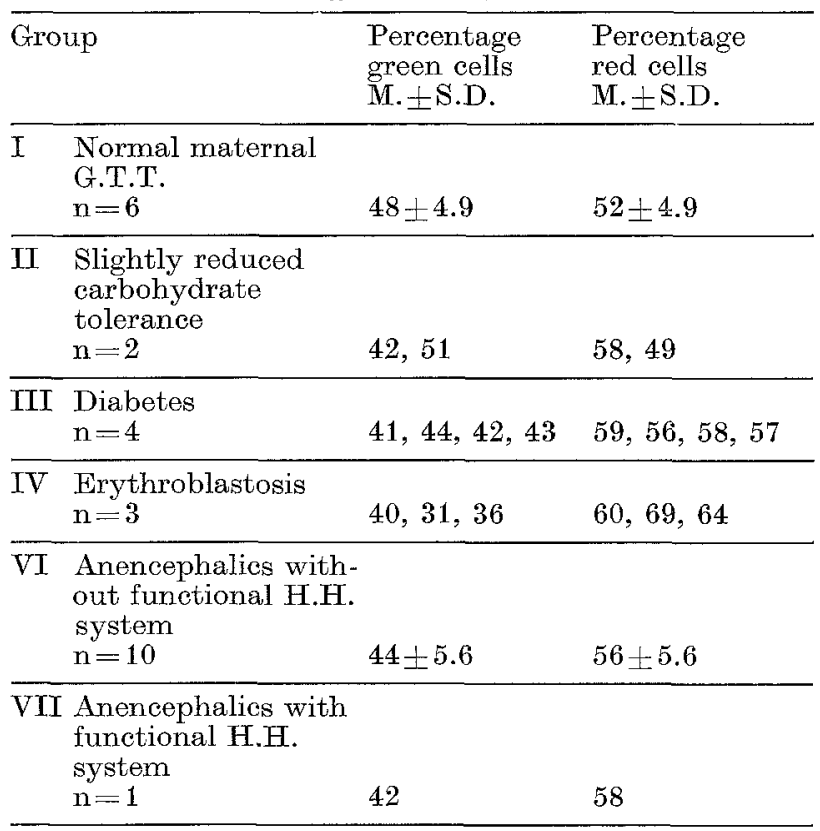

A statistically significant increase $(p<0.05)$ in the proportion of $\mathrm{Ag}+$ cells was found in infants of diabetic mothers (group IIT). In comparison with the infants from normoglycaemic mothers (group I) and erythroblastotic babies (group IV), an increased proportion of $\mathrm{Ag}+$ cells was observed in infants from mothers with slightly reduced carbohydrate tolerance (group II) and in anencephalics of a diabetic mother, provided that the foetal hypophysis was active (group VII b). The increase is not statistically significant, due to the small number of cases and also to the large variation of individual values.

Table 5. Comparison between $\mathrm{Ag}^{+}$and Phloxine ${ }^{+}$cells

\begin{tabular}{|c|c|c|c|c|}
\hline \multicolumn{2}{|c|}{ Group } & $\begin{array}{l}\text { Percentage } \\
\text { Phloxine } \\
\text { cells } \\
\text { M. } \pm \text { S.D. }\end{array}$ & $\begin{array}{l}\text { Percentage } \\
\text { Ag+ } \\
\text { cellsa } \\
\text { M. } \pm \text { S.D. }\end{array}$ & $\begin{array}{l}\text { Percentage } \\
\text { Agt } \\
\text { Phloxine } \\
\text { cells } \\
\text { M. IS.D. }\end{array}$ \\
\hline $\mathrm{I}$ & $\begin{array}{l}\text { Normal mater- } \\
\text { nal G.T.T. } \\
n=12\end{array}$ & $62 \pm \quad 5.8$ & $40.5 \pm 8.6$ & $65 \pm 13.0$ \\
\hline II & $\begin{array}{l}\text { Slightly re- } \\
\text { duced carbo- } \\
\text { hydrate toler- } \\
\text { ance } \\
n=4\end{array}$ & $47 \pm 5.6$ & $36.5 \pm 6.2$ & $77 \pm 27.8$ \\
\hline III ] & $\begin{array}{l}\text { Diabetes } \\
n=6\end{array}$ & $35 \pm 10.3$ & $31 \pm 8.4$ & $88 \pm 33.1$ \\
\hline IV 1 & $\begin{array}{l}\text { Erythroblastosi } \\
n=6\end{array}$ & $55 \pm 8.1$ & $31 \pm 9.5$ & $56 \pm 13.3$ \\
\hline 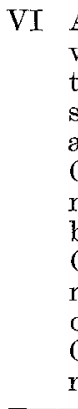 & $\begin{array}{l}\text { Anencephalics } \\
\text { without func- } \\
\text { tional H.H. } \\
\text { system } \\
\text { a) Normal } \\
\text { G.T.T. } \\
\text { n=3 } \\
\text { b) Abnormal } \\
\text { G.T.T. } \\
\text { n=6 } \\
\text { c) Without } \\
\text { G.T.T. } \\
\text { n=4 }\end{array}$ & $\begin{array}{l}62 \pm 5.0 \\
66 \pm 10.8 \\
63 \pm 11.1\end{array}$ & $\begin{array}{l}45 \pm 1.7 \\
41 \pm 4.0 \\
43 \pm 4.6\end{array}$ & $\begin{array}{l}72 \pm 4.3 \\
62 \pm 9.9 \\
68 \pm 10.7\end{array}$ \\
\hline VII & $\begin{array}{l}\text { Anencephalics } \\
\text { with functional } \\
\text { H.H. system } \\
\text { a) Normal } \\
\text { G.T.T. } \\
\text { n=2 } \\
\text { b) Abnormal } \\
\text { G.T.T. } \\
\text { n=3 }\end{array}$ & $\begin{array}{l}58 \pm 2.8 \\
38 \pm 7.3\end{array}$ & $\begin{array}{l}37 \pm 6.3 \\
29 \pm 1.0\end{array}$ & $\begin{array}{l}64 \pm 7.7 \\
77 \pm 19.6\end{array}$ \\
\hline
\end{tabular}

a Hellerström-Hellman

\section{Comparison between the different cell types}

a) Quantitative methods. A comparison between the proportion of different non-B cells as demonstrated with different staining techniques, shows that AFcells are less frequent than green (D ?) cells, that green cells are less frequent than $\mathrm{Ag}+$ cells, and that $\mathrm{Ag}+$ cells are less frequent than phloxine-positive cells (Table 6). This is also true for the individual cases in all groups, except for one case in group II and for 
three cases of group III, where more $\mathrm{Ag}+$ cells than phloxine-positive cells are found. The fact that with the different staining techniques the percentage of the respective types of non-B cells varies, whereas on the other hand no parallel variations of these cell types occur in different clinical conditions, argues strongly against a relationship between staining characteristics and functional activity.

\section{b) Qualitalive methods. - Alternate sections.}

In alternate sections ( $3 \mu$ thickness) we found argyrophilic cells in some islets, which in the alternate sections contain granules of the B cell type (Figs. $6-7$ ).

\section{Discussion}

Our study of the cytological composition of the islets demonstrates that only one cell type, the B cell, can be constantly identified with the different staining techniques. The other islet cells represent an heterogeneous group, whose components vary according to the staining method used.

With Gomori's chrome-alum haematoxylin-phloxine technique only one type of non-B cells is found. With the Ivic technique two types of non-B cells can be demonstrated: the acid-fuchsin-negative ( $\mathrm{AF}-$ ) and the acid-fuchsin-positive $(\mathrm{AF}+)$ cells. The $\mathrm{AF}-$ ressemble the $\mathrm{C}$ cells, which Bensley [1] described in

Table 6. Comparison between the different non-B cells in the studied groups Phloxine-positive cells are considered as $100 \%$. Acid-fuchsin-negative cells are less frequent than green cells; green cells are less frequent than argyrophilic ( $\left.\mathrm{Ag}^{+}\right)$cells; and $\mathrm{Ag}^{+}$cells are less frequent than phloxine-positive cells. However, this does not mean that $\mathrm{AF}$ - cells are always green cells and that green cells are always $\mathrm{Ag}^{+}$. The proportion of $\mathrm{Ag}^{+}$cells out of phloxine-positive cells is increased in groups II, III and VIIb.

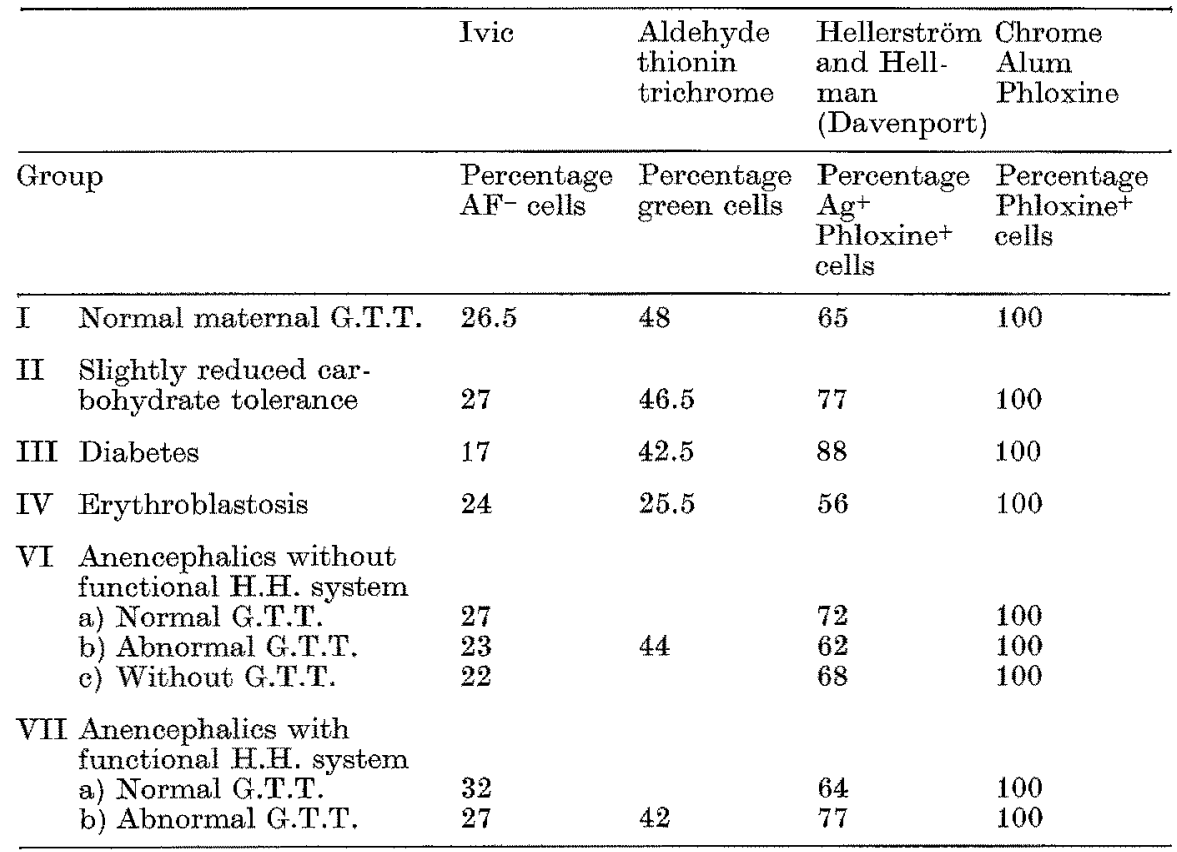

- Slides re-stained by Ivic's method after removal of the silver (Hellerström-Hellman method):

We were unable to obtain satisfactory results in slides re-stained by Ivic's method or by the aldehydethionin-trichrome technique after removal of silver.

- Slides counterstained with aldehyde-thionin-trichrome technique after Holmes technique:

In such slides we found, besides cells strongly impregnated with silver and unimpregnated B cells, a small number of unimpregnated green (D) cells (Fig. 8) and also a small number of B cells with black silver granules (Fig. 9). the guinea pig, after staining by the gentian-violet fuchsin method. With aldehyde-thionin-trichrome two types of non-B cells are seen: green cells and red cells. The green cells as well as the AF - cells are located in the peripheral area of the islet. The green cells probably correspond to those that have been described and called $\mathrm{D}$ cells by Bloom [4]. Conklin [8] suggests that the $\mathrm{D}$ cells are immature $\mathrm{B}$ cells. Moreover, he observed grey cells, which he considered to be cells stained both with light green (as D cells) and with aldehyde fuchsin (as B cells). In our opinion these grey cells could be degranulated $B$ cells; we are not 

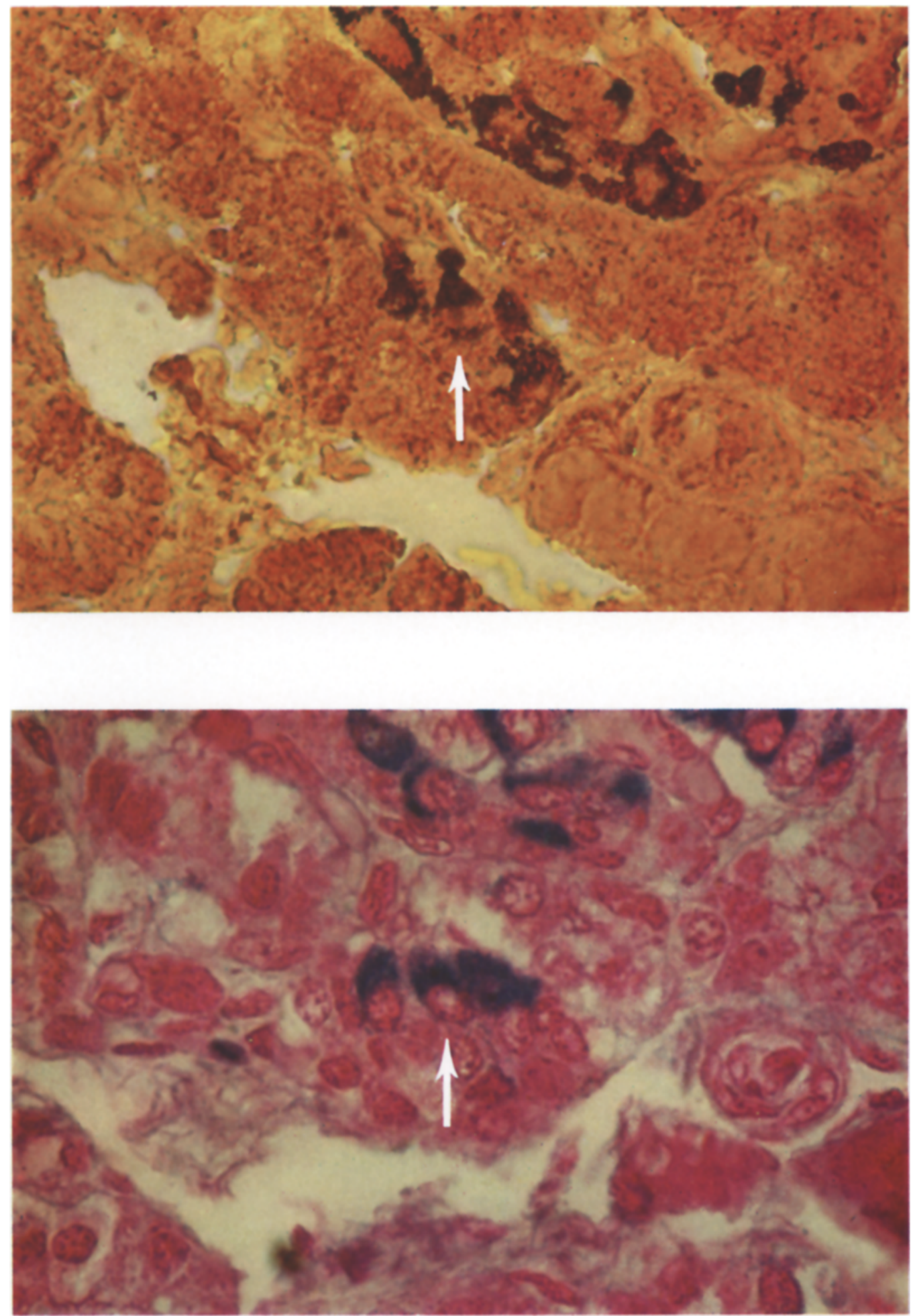

Figs. 6 and 7. Three argyrophilic cells contain at the alternate section granules of the $B$ cell type Two alternate sections stained with the silver impregnation technique to Hellerström-Hellman and with Ivic's method 


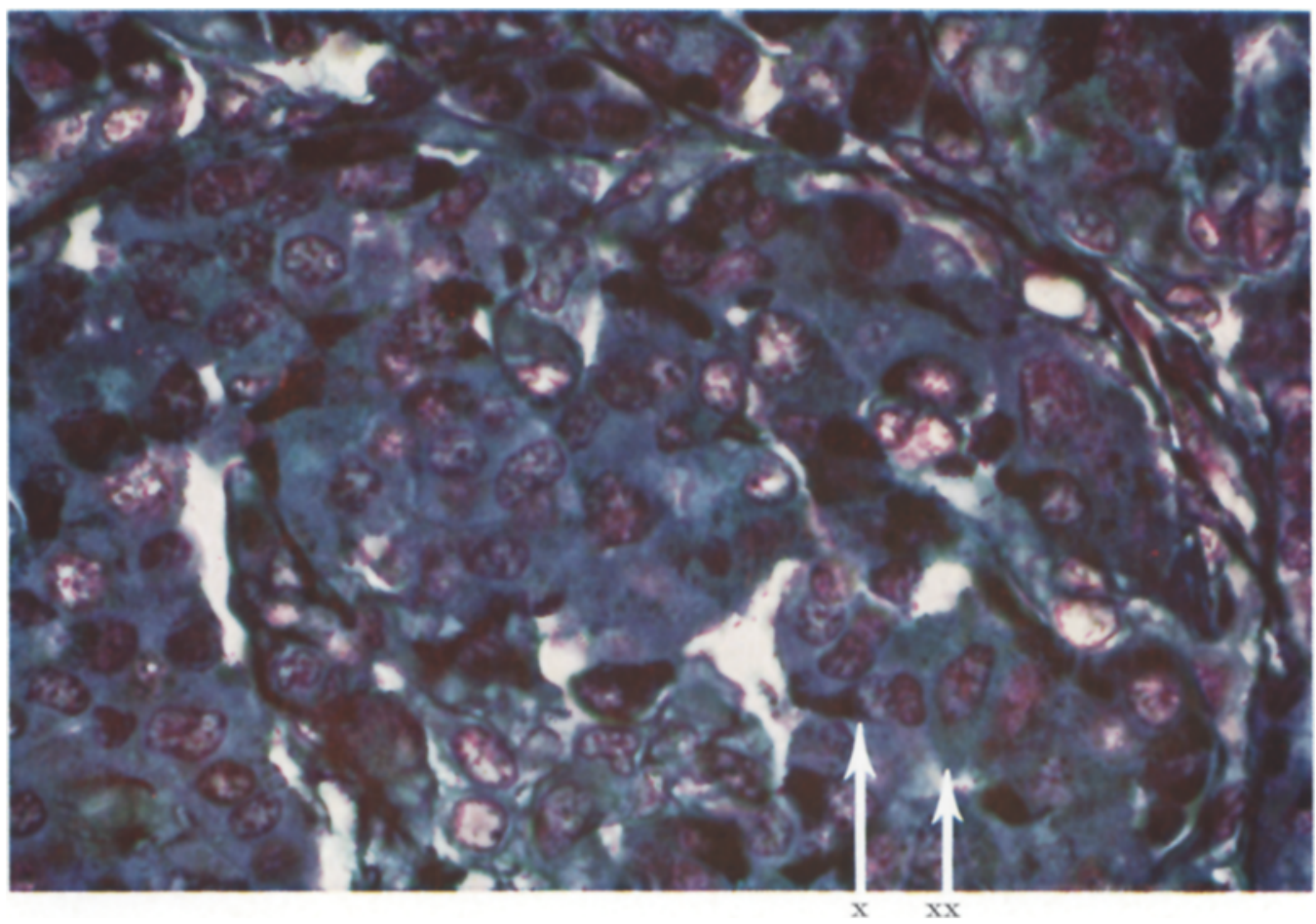

Fig. 8. We can see completely black cells (X), and light green coloured cells (XX) Slide counterstained with aldehyde thionin trichrome after Holmes technique

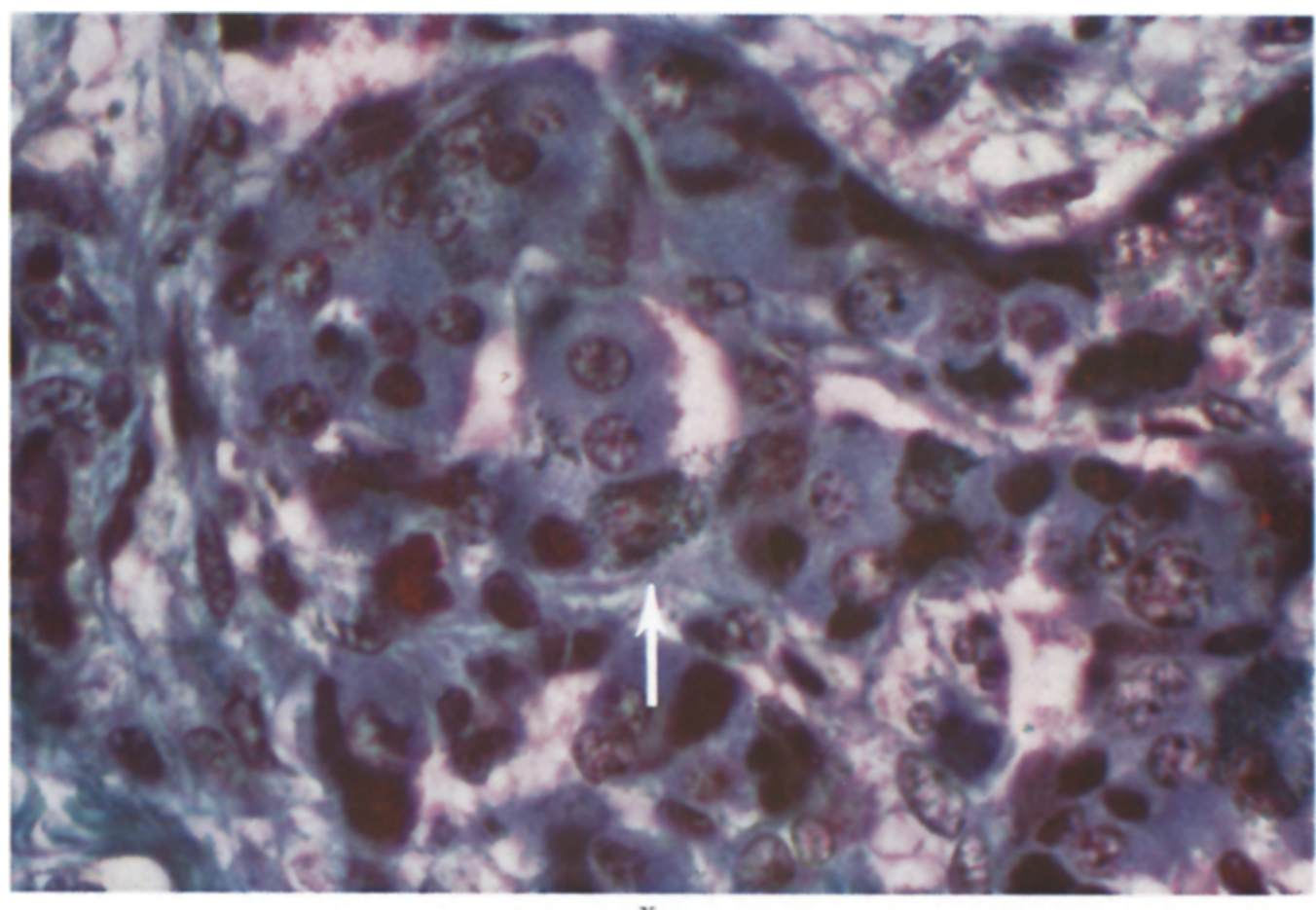

$\mathbf{x}$

Fig. 9. A few cells contain blue and black granules in their cytoplasma (X) Slide counterstained with aldehyde thionin trichrome after Holmes technique 
convinced that they represent immature B cells. Like [28] doubts the existence of the $D$ cell as a separate cell type.

Numerous silver impregnation techniques have been proposed for the study of the islets of Langerhans. It has been pointed out and confirmed by our study that these different techniques do not impregnate the same type of cells. With the Davenport technique and its modification by Hellerström and Hellman [18], less cells are blackened than with the Grimelius [17] or Holmes [22] technique. Moreover, in some cases we found more silver impregnated cells than non-B cells. This suggests that the silver-impregnation technique not only impregnates non-B cells, but also a variable number of $\bar{B}$ cells. This suggestion is confirmed by the study of slides impregnated with silver by the Holmes technique, and counterstained with aldehyde thionin trichrome. In such preparations cells that contain both blue and black granules can be found.

The Swedish group $[3,19,20]$ in comparing preparations impregnated with silver by a modified Davenport method with the same preparations after removal of silver and re-staining with aldehyde fuchsin, state that only a part of the A cells are silver positive. They divide the A cells into two groups: $\mathrm{A}^{1}$ cells (argyrophilic) and $\mathrm{A}^{2}$ cells (non-argyrophilic). These authors have never found an argyrophilic cell containing granules of the B cell type. However, in our hands, granule staining after silver removal gave unreliable results.

We disagree with Fujita [14] and Epple [12], who stated that the $D$ cell is identical with the silverpositive cell. Indeed, in silver-impregnated sections counterstained with aldehyde thionin we found green cells (D cells) unimpregnated with silver.

On the basis of the studies of our group with the light and electron microscope, our opinion is that four types of cells can be identified in human pancreatic islets: B cells, A cells, a third type of cell, which probably secretes gastrin, and a fourth type of cell, the function of which remains obscure [10]. In the islets of the newborn infants, the $B$ cells constitute the central core, whereas the peripheral mantle is composed of non-B cells. In the adult, the cell types are intermingled all over the islets $[10,15]$. Björkman et al. [3] and Hellman [19] found 4 types of cells in the endocrine pancreas of the human: $A^{1}$ cells, $A^{2}$ cells, $B$ cells and agranular cells. De Coninck et al. [10], however, were unable to find agranular cells. They feel that the D cells of Bloom may constitute an heterogeneous group, composed of cells which probably secrete gastrin and another cell type of unknown functional significance.

$B$ cell hyperplasia and an increased proportion of $\mathrm{Ag}+$ cells in the islets of the newborn are, in comparison with macropolynesia, more specific parameters for the detection of maternal diabetes, since these parameters are not found in anti-D erythroblastosis foetalis or in haemolysis due to alpha-thalassaemia. It is also interesting to point out that an increased number of such cells is found in different types of hyperglycaemia in animals and in $\operatorname{man}[14,21,26]$.

The hypothalamo-hypophyseal system is not involved in the basal maturation process of the foetal islets of Langerhans. However, hyperplasia of the islets of the $B$ cells, such as found in offspring of diabetic mothers, can develop only when this system is present and functional. This conclusion can be derived from the fact that anencephalic babies from diabetic mothers fail to develop hyperplasia, when the hypothalamo-hypophyseal system has not been functional.

Whether this effect is a direct one or is mediated through other endocrine glands, cannot be demonstrated at the present time [40].

Acknowledgements. We wish to thank Mrs. Van Bastelaere-Declercq for her valuable technical assistance and also Professor Renaer for suggestions and help. The help of Mr. K. Dergent (Ortho Pharmaceutica) in preparing the coloured slides is greatly appreciated.

\section{Bibliography}

1. Bensley, R. R.: Studies on the pancreas of the guineapig. Amer. J. Anat. 12, 297-338 (1911).

2. Berblinger, $W_{\text {.: }}$ Der Morbus haemoliticus der Neugeborenen. Virchows Arch. path. Anat. 322, 1-16 (1952).

3. Björkman, N., Hellerström, C., Hellman, B., Petersson, B.: The cell types in the endocrine pancreas of the human fetus. Z. Zellforsch. 72, 425-445 (1966).

4. Bloom, W.: A new type of granular cell in the islets of Langerhans in man. Anat. Rec. 49, 363-371 (1931).

5. Brähler, H.J. n. Hellweg-Dallenbach, G.: Die Langerhansschen Inseln bei fetalen Erythroblastose. Virchows Arch. path. Anat. 336, 544-549 (1963).

6. Cardell, B.S.: Hypertrophy and hyperplasia of the pancreatic islets in newborn infants. J. Path. Bact. 66, 335-346 (1953).

7. Cavallero, C., Solcia, I.: Cytologic and cytochemical studies on the pancreatic islets. Ed. by Brolin, S.E., Hellman, B., and Knutson, H.: The structure and metabolism of the pancreatic islets. P. 83 , proc. 3 . Wenner-Gren Center Int. Symp., Uppsala and Stockholm, 1963. London: Pergannon Press 1964.

8. Conklin, J.L.: Cytogenesis of the human fetal pancreas. Amer. J. Anat. 111, 181-193 (1962).

9. d'Agostino, A.N., Bahn, R.C.: A histopathologic study of the pancreas of infants of diabetic mothers. Diabetes 12, 327-331 (1963).

10. De Coninck, J., Gepts, W., Van Assche, F.A.: Electron microscopy of the human fetal pancreas, to be published

11. Driscoll, S. G., Benirschke, K., Curties, G. W. : Neonatal deaths among infants of diabetic mothers. Postpartum findings in ninety-five infants. Amer. J. Dis. Child. 100, 818 - 835 (1960).

12. Epple, A.: Zur vergleichenden Zytologie des Inselorgans. Verh. Dout. Zool. Ges. 1963. Ergänz. z. Zool. Anz. 27, 461-470 (1964).

13. Ferner, H., Stoeckenius, W., jr.: Die Cytogenese des Inselsystems beim Menschen. Z. Zellforsch. 35, 147175 (1951).

14. Fujita, T.: D cell, the third endocrine element of the pancreatic islet, Arch. Histol. Jap. 29, 1-40 (1968). 
15. Gepts, W.: Die histopathologische Veränderungen der Langerhanschen Inseln und ihre Bedeutung in der Frage der Pathogenese des menschlichen Diabetes. Endokrinologie 36, 185-211 (1958).

16. Gomori, G.O.: Observations with differential stains on human islets of Langerhans. Amer. J. Path. 17, $395-406$ (1941).

17. Grimelius, L.: A modified silver protein method for study in the argyrophilie cells of the islets of Langer. hans. Ed. by Brolin, S.E., Hellman, B., Knutson, H.: The structure and metabolism of the pancreatic islets, pp. 99. Proc. 3. Wenner-Gren Center Int. Sympos. Uppsala and Stockholm 1963. London: Pergamon Press 1964.

18. Hellerström, C., Hellman, B.: Some aspects of silver impregnation of the islets of Langerhans in the rat. Acta endocrin. (Kbh.) 35, 418-432 (1960).

19. Hellman, B.: The development of the mammalian endocrine pancreas. Biol. Neonat. 9, 263 - 278 (1966).

20. - Hellerström, C.: Cellular composition of the islets of Langerhans in the bullfrog, Rana Catesbiana. Acta anat. $48,149-155(1962)$.

21. - Peterson, B.: Long term changes of the $A_{1}$ and $A_{2}$ cells in the islets of Langerhans of rats with alloxan diabetes. Endocrinology 72, 238-242 (1963).

22. Holmes, W.: Recent advances in clinical pathology. London: Churehill 1947.

23. Hultquist, G.T., Odding, L., Larsson, Y.A.A.: Some histopathologic quantitative observations on the pancreatic islets of infants of diabetic mothers. Abstracts fifth Congress Int. Diab. Ass. med. Int, Congr. Series, 47, Abstract. 129 (1964).

24. Ivic, M. : Neue selektive Färbungsmethode der $\mathrm{A}$ und B Zellen der Langerhans Inseln. Anat. Anz. 107, 347$350(1959)$.

25. Jackson, W.P.U., Woolf, N.: Maternal prediabetes as a cause of unexplained stillbirth. Diabetes $7,446-448$ (1958).

26. Kobayashi, K., Takabashi, Y., Johshita, T.: Influences of alloxan administration and hypophysectomy on the pancreatic islets of the rat. Arch. Histol. Jap. 25, 199-216 (1964).

27. Lie-Injo, L.J., Lopez, C.G., Dutt, A.K.: Pathological findings in hydrops fetalis due to alpha-thalassemia. A review of 32 cases. Trans. roy. Soc. trop. Med. Hyg. $62,874-879(1968)$.

28. Like, A. A.: The ultrastructure of the secretory cells of Langerhans in man. Lab. Invest. 16, 937-951 (1967).

29. Lomsky, R., Langr, F., Vortel, V.: Immunohistochemical demonstration of gastrin in mammalian islets of Langerhans. Nature (Lond.) 223, 618-619 (1969).
30. Miller, H.C.: Effect of diabetic and prediabetic pregnancy on fetuses and newborn infants. J. Pediatr. 29, $445-461$ (1946)

31. Naeye, R.L.: Infants of diabetic mothers: a quantitaw tive morphologic study. Pediatrics 35, 980-989 (1965).

32. Nelson, H.: A photometric adaptation of the somogyi method for determination of glucose. J, biol. Chem. 153, 375-380 (1944).

33. Paget, G. E.: Aldehyde thionin: A stain having similar properties to aldehyde fuchsin. Stain Techn. 34, 223226 (1959).

34. Potter, E. L. : Pathology of the fetus and infant, p. 334. Chicago: Gitaro 1952.

35. Robb, P.: The development of the islets of Langerhans in the human fetus. Quart. J. exp. Physiol. 46,335343 (1961).

36. Schultze-Jena, B.S.: Das quantitative und qualitative Inselbild menschlicher Feten und Neugeborenen. Virchows Archiv. 323, 653-663 (1953).

37. Silverman, J.L.: Eosinophile infiltration in the pancreas of infants of diabetic mothers. A clinicopathologic study. Diabetes 12, 528-537 (1963).

38. Van Assche, F.A.: Histologisch en histochemisch onderzoek van de eilandjes van Langerhans bij de foetus in verband met de opsporing van diabetes en verlaagde koolhydratentolerantie bij de moeder. Wedstrijd voor het toekennen van reisbeurzen 1965 .

39. - A morphological study of the Langerhans' islets of the fetal pancreas in late pregnancy. Biol. Neonat. 12, $331-342$ (1968).

40. - Gepts, W., de Gasparo, M.: The endocrine pancreas in anencephalics. Biol. Neonat. 14, 374-388 (1969).

41. Van Beek, C.: Kan men aan een doodgeborene de diagnose diabetes mellitus der moeder stellen. Ned. T. Geneesk. 83, 5973-5979 (1939).

42. Warren, S., Lecompte, P.M.: The pathology of diabetes mellitus. p. 248. Philadelphia: Lea and Febiger 1952.

Dr. F.A. Van Assche

Dept. Obst. and Gynaec.

University Hospital St. Raphaël

B-3000 Leuven, Belgium

Prof. Dr. W. Gepts

Dept. of Pathology

Brugman Hospital, Univ. of Brussels

B-1020 Brussels,

Belgium 